\title{
PENGARUH POTENSI KEBANGKRUTAN PERUSAHAAN PUBLIK TERHADAP PERGANTIAN AUDITOR
}

\author{
Theresia Niken Setyorini \\ Aloysia Yanti Ardiati \\ Universitas Atma Jaya Yogyakarta
}

\begin{abstract}
The main objective of this paper is to examine the effect of failing firms (firms which are potential to be bankrupt) on auditor switching. Hypothesis was derived from Schwartz and Menon (1985) which implies that failing firms have a greater tendency to switch auditors than healthier firms do. The $Z$ score (Altman model) was used as a proxy to measure the potential of bankruptcy. This method was applied since it has been developed in several countries such as US, Germany, Brazil, Australia, England, Ireland, Canada, the Netherlands, and France. Annual report and Indonesian Capital Market Directory were used to collect the data for a sample of 7 firms that changed their auditors and 7 firms that did not. Those four-teen (14) firms have been selected as sample among firms in consumer goods industries to answer the question about the impact of firns with potential to go bankrupt on auditor switching. Chi-Square result shows that firms with potential to go bankrupt could not influence auditor switching.
\end{abstract}

Keywords: auditor switching, bankruptcy, Altman Z-Score, failing firm

\section{PENDAHULUAN}

Akuntan Publik (Auditor Independent) memiliki peranan yang sangat penting bagi perusahaan publik (go public). Akuntan Publik bertugas memeriksa laporan keuangan perusahaan secara obyektif dengan mengumpulkan dan mengevaluasi bukti yang cukup yang berkaitan dengan laporan keuangan perusahaan yang bersangkutan, sehingga hasil pemeriksaan berguna untuk menentukan bahwa laporan keuangan tersebut sudah disajikan secara wajar sesuai dengan prinsip akuntansi yang berterima umum dan memiliki kredibilitas (dapat dipercaya oleh publik).

Laporan keuangan perusahaan publik sangat dibutuhkan oleh berbagai pihak baik di dalam perusahaan maupun di luar perusahaan. Pihak-pihak yang berkepentingan pada laporan keuangan perusahaan disebut pemakai laporan keuangan yang terdiri dari pimpinan perusahaan, manajemen perusahaan, pemegang saham (investor) maupun calon investor, kreditor maupun calon kreditor, pemerintah, dan masyarakat. Pimpinan dan manajemen perusahaan ingin menyampaikan informasi mengenai pertanggungjawaban pengelolaan dana yang berasal dari pihak luar; di pihak lain, pihak di luar perusahaan ingin memperoleh informasi yang dapat dipercaya. Adanya dua kepentingan yang berlawanan inilah yang menyebabkan timbul dan berkembangnya profesi akuntan publik.

Timbul dan berkembangnya profesi akuntan publik sangat dipengaruhi perkembangan perusahaan pada umumnya. Semakin banyak perusahaan publik, semakin banyak pula jasa akuntan publik yang dibutuhkan, oleh karena itu Kantor Akuntan Publik (KAP) saling bersaing untuk mendapatkan klien (perusahaan publik) dengan cara berusaha memberikan jasa audit sebaik mungkin. Perusahaan selain dapat meminta jasa audit kepada KAP untuk audit yang pertama, dapat juga meminta jasa audit untuk kondisi pergantian audit (Boynton dan Kell, 1996: 191).

Berkaitan dengan pergantian auditor, SEC (Securities and Exchange Commission) mengeluarkan pernyataan mengenai pergantian auditor pada nomor Accounting Series Releases (ASR) yaitu SEC ASR No. 
165 (1974), No. 194 (1976), No. 247 (1978). Pernyataan tersebut bertujuan untuk mencegah manajemen mengganti KAP agar dapat memperoleh unqualified opinion atau perlakuan akuntansi yang lebih baik atau menguntungkan (Schwartz dan Menon, 1985).

Dalam perkembangannya, muncul banyak permasalahan yang mendorong perusahaan untuk mengganti auditor. Beberapa literatur akuntansi menuliskan faktor-faktor yang mendorong perusahaan untuk mengganti auditornya, yaitu: adanya perubahan manajemen (Burton dan Roberts, 1967 dalam Schwartz dan Menon, 1985), adanya keinginan perusahaan supaya laporan keuangannya dapat lebih dipercaya (Carpenter dan Strawser, 1971 dalam Schwartz dan Menon, 1985), audit fee dan hubungan kerja yang baik (didefinisikan sebagai respon KAP terhadap kebutuhan klien) sebagai dua faktor yang paling mempengaruhi seleksi auditor (Eichenser dan Shield, 1983 dalam Schwartz dan Menon, 1985), ketidakpuasan atas pendapat auditor (Chow dan Rice, 1982 dalam Schwartz dan Menon, 1985), perubahan metoda akuntansi yang digunakan manajemen (DeAngelo, 1982 dalam Schwartz dan Menon, 1985). Melihat banyaknya faktor-faktor yang dapat mempengaruhi pergantian auditor tersebut, Schwartz dan Menon (1985) menyatakan bahwa faktor-faktor yang mempengaruhi pergantian auditor pada perusahaan yang sehat berbeda dengan faktor-faktor yang mempengaruhi pergantian auditor pada perusahaan berpotensi bangkrut.

Schwartz dan Menon (1985) mempertimbangkan potensi kebangkrutan sebagai variabel yang mempengaruhi pergantian auditor. Potensi kebangkrutan merupakan kesulitan solvabilitas yaitu kewajiban keuangan perusahaan sudah melebihi kekayaannya, apabila prospek perusahaan tidak memberikan harapan maka likuidasi terpaksa ditempuh. Potensi kebangkrutan termasük dalam kondisi kesulitan keuangan yang tingkat kesulitannya lebih besar dari kesulitan likuiditas (technical insolvency), yang dimaksud di sini adalah perusahaan hanya tidak mampu memenuhi kewajiban keuangan sementara waktu.

Untuk mengetahui apakah suatu perusahaan berpotensi bangkrut atau tidak, bisa dilihat dengan menggunakan alat analisis keuangan Multiple Discriminant Analysis (Z Score). Z Score ini adalah bentuk analisis keuangan yang menggunakan rasio-rasio keuangan yang dikombinasikan menjadi persamaan matematis. Rasio-rasio yang digunakan mewakili rasio-rasio keuangan secara keseluruhan. Model Z Score ini ditemukan oleh Altman (1968), yang selanjutnya diperbaharui pada tahun 1984 di beberapa negara. Z Score yang telah direvisi pada tahun 1984 telah berdimensi Internasional (Foster, 1986: 551 dalam Supardi dan Sri Mastuti, 2003).

Schwartz dan Menon (1985) menyatakan bahwa di dalam lingkungan perusahaan berpotensi bangkrut terdapat pengaruh yang besar terhadap putusnya hubungan kerja antara manajemen dan auditor yang menyebabkan perusahaan mengganti auditornya, seperti adanya permasalahan metoda akuntansi, ketidakpuasan atas pendapat auditor, atau ketidakpuasan terhadap kinerja auditor. Permasalahanpermasalahan di atas menyebabkan ketegangan hubungan antara manajemen dan auditor, serta timbulnya perbedaan pendapat yang tidak dapat disatukan lagi (Schwartz dan Menon,1985).

Kesulitan keuangan yang terdiri dari kesulitan likuiditas sampai dengan kondisi perusahaan berpotensi bangkrut disebabkan oleh banyak hal, baik dari luar maupun dari dalam perusahaan. Meskipun sebab-sebab terjadinya kesulitan keuangan sangat bervariasi, tetapi kebanyakan penyebabnya adalah karena serangkaian keputusan manajemen yang salah sehingga kondisi perusahaan memburuk. Perusahaan berpotensi bangkrut memiliki kecenderungan mengganti auditornya karena dalam perusahaan berpotensi bangkrut, terdapat pengaruh yang besar terhadap putusnya hubungan kerja antara manajemen dan auditor, yang dapat memicu perusahaan untuk melakukan pergantian auditor.Berdasarkan kondisi tersebut, penelitian ini bertujuan membuktikan pengaruh potensi kebangkrutan perusahaan publik terhadap pergantian auditor dengan mengambil data perusahaan publik yang terdaftar di Bursa Efek Jakarta (BEJ).

\section{TELAAH LITERATUR DAN PENGEMBANGAN HIPOTESIS}

Perusahaan publik memiliki laporan keuangan yang sangat dibutuhkan oleh pihak-pihak yang berkepentingan untuk pengambilan keputusan. Dengan demikian perusahaan publik sangat membutuhkan jasa auditor untuk menjamin apakah laporan keuangannya sudah disajikan secara wajar sesuai dengan prinsip akuntansi yang diterima umum, sehingga laporan keuangannya memiliki kredibilitas atau dapat dipercaya. Perusahaan selain dapat meminta jasa audit kepada KAP untuk audit yang pertama, dapat juga 
meminta jasa audit untuk kondisi pergantian audit (Boynton dan Kell, 1996: 191). Schwartz dan Menon (1985) menyatakan bahwa faktor-faktor yang mempengaruhi pergantian auditor pada perusahaan yang sehat berbeda dengan faktor-faktor yang mempengaruhi pergantian auditor pada perusahaan yang berpotensi bangkrut. Perusahaan yang berpotensi bangkrut lebih cenderung melakukan pergantian auditor dibandingkan perusahaan yang sehat karena di dalam lingkungan perusahaan berpotensi bangkrut terdapat pengaruh yang besar terhadap putusnya hubungan kerja antara manajemen dan auditor, seperti adanya permasalahan metoda akuntansi, ketidakpuasan terhadap pendapat auditor, atau ketidakpuasan terhadap kinerja auditor (Schwartz dan Menon, 1985).

Potensi kebangkrutan yang dialami perusahaan dapat diketahui dengan analisis laporan keuangan multivariate. Analisis terhadap laporan keuangan dapat meramalkan kontinuitas atau kelangsungan hidup perusahaan dan memprediksi kebangkrutan yang mungkin menimpa perusahaan di masa yang akan datang. Dugaan adanya pengaruh potensi kebangkrutan perusahaan publik terhadap pergantian auditor akan diteliti dalam penelitian ini.

\subsection{Analisa Laporan Keuangan Untuk Mengidentifikasikan Potensi Kebangkrutan Perusahaan}

Laporan keuangan merupakan alat yang sangat penting untuk memperoleh informasi sehubungan dengan posisi keuangan dan hasil-hasil yang telah dicapai perusahaan yang bersangkutan. Ada berbagai alat untuk mendeteksi dan meramalkan kemungkinan terjadinya kesulitan keuangan mulai dari kesulitan likuiditas sampai dengan potensi kebangkrutan yaitu pertama, Analisa Data Ekstern, data ekstern yang biasanya digunakan ialah data-data industri, data statistik dan indikator ekonomi yang diterbitkan oleh instansi pemerintah maupun pihak swasta; kedua, Analisa Data Intern, analisa data intern biasanya bersumber pada penemuan dan saran-saran yang dikemukakan oleh akuntan publik dari hasil pemeriksaannya kepada manajemen. Dengan menggunakan data intern, analisa yang dilakukan sebagai berikut: pertama, Analisa Trend yang merupakan analisa terhadap laporan keuangan perusahaan yang mencakup beberapa periode tahun buku, maka dapat diperoleh informasi tentang penurunan atau kelemahan posisi kas, kekurangan modal kerja, overinvestment dalam piutang, persediaan atau aktiva tetap, kenaikan utang dan penundaan utang yang telah jatuh tempo; kedua, Analisa Rasio biasanya lebih bermanfaat dan mampu menunjukkan adanya kekuatan atau kelemahan-kelemahan finansial perusahaan. Rasio keuangan sangat banyak, karena rasio dapat dibuat menurut kebutuhan penganalisa. Namun, secara umum rasio keuangan dapat digolongkan menjadi enam jenis yaitu rasio likuiditas, rasio leverage, rasio aktivitas, rasio profitabilitas, rasio pertumbuhan (growth ratios), dan rasio penilaian (valuation ratios).

Analisis laporan keuangan menggunakan rasio keuangan dibagi menjadi dua macam cara yaitu model univariate dan model multivariate. Model univariate yaitu menganalisis laporan keuangan dengan rasio-rasio keuangan yang sudah ada. Penggunaan analisis rasio secara univariate dalam menentukan perusahaan-perusahaan yang berpotensial bangkrut, secara teoritis maupun praktis mempunyai kelemahan. Dalam setiap kasus, analisis rasio dengan metode univariate ini ditekankan atau difokuskan pada sebuah rasio untuk masalah tersebut. Analisis dengan cara demikian dapat mengakibatkan kesalahan interpretasi. Sebagai contoh perusahaan yang mempunyai solvabilitas dan atau profitabilitas yang jelek dapat diindikasikan akan mengalami kebangkrutan. Namun karena likuiditasnya berada di atas rata-rata industri maka situasi tersebut mungkin tidak akan ditanggapi secara serius. Keterbatasan atau kelemahan yang ada dalam model univariate analisis dapat diatasi dengan cara mengkombinasikan beberapa variabel (rasio) keuangan ke dalam sebuah model multivariate yaitu Multiple Discriminant Analysis (MDA).

Kelebihan dari MDA yaitu: MDA merupakan penggabungan dari kumpulan rasio-rasio yang simultan; MDA merupakan ketentuan koefisien yang tepat untuk mengkombinasikan variabelvariabel independen; dan MDA merupakan perbaikan suatu aplikasi model awal (univariate) yang telah dikembangkan.

Model multivariate dalam analisis MDA yang digunakan untuk menganalisis potensi kebangkrutan pertama kali ditemukan oleh Edward Altman pada tahun 1968 di Amerika. MDA hasil 
penelitian Altman (1968) berupa persamaan Z Score. Z Score adalah skor yang ditentukan dari hitungan standar kali rasio-rasio keuangan yang akan menunjukkan tingkat kemungkinan kebangkrutan perusahaan. Dalam kaitannya dengan data rasio keuangan dan kegunaannya, Altman (1981) mengemukakan 22 rasio keuangan yang tercakup dalam lima rasio yang penting yaitu rasio modal kerja/total aktiva, rasio laba ditahan/total aktiva, rasio Earning Before Interest and $\operatorname{Tax}(\mathrm{EBIT}) /$ total aktiva, rasio harga pasar saham/nilai buku total utang, dan rasio penjualan/total aktiva.

Persamaan $Z$ Score Altman tersebut adalah (Altman, 1993: 182):

$$
Z=0,012 X_{1}+0,014 X_{2}+0,033 X_{3}+0,006 X_{4}+0,999 X_{5}
$$

Namun persamaan $Z$ Score Altman tahun 1968 ini mempunyai kelemahan yaitu (Newton, 2000: 56): persamaan tersebut merupakan hasil penelitian di Amerika, jadi apabila diterapkan di negara lain kondisinya belum tentu sesuai. Cut of score (ambang batas) Z Score ditemukan Altman berdasarkan kondisi negara Amerika. Dengan kata lain, persamaan Z Score tersebut belum berdimensi Internasional; dan persamaan Z Score ini hanya dapat diterapkan pada perusahaan publik saja. Hal ini dapat dilihat dari rasio harga pasar saham/nilai buku total utang. Jadi persamaan Z Score Altman hasil penelitiannya tahun 1968 mempunyai lingkup yang masih sangat sempit.

Pada perkembangannya, Altman melakukan penelitian lagi di beberapa negara seperti United State, Japan, Jerman, Switzerland, Brasil, Australia, Inggris, Kanada, Belanda, dan Perancis (Foster, 1986: 551 dalam Supardi dan Sri Mastuti, 2003). Penelitian lanjutan ini dilakukan Altman pada tahun 1984 untuk mengatasi kelemahan persamaan Z Score yang pertama. Penelitian Ianjutan Altman ini sudah berdimensi Internasional, selain itu persamaan Z Score hasil penelitiannya tahun 1984 ini juga bisa diterapkan pada perusahaan publik maupun tidak publik. Hal tersebut dapat dilihat dari rasio harga pasar saham/nilai buku total utang yang dapat diubah menjadi rasio nilai buku saham/nilai buku total utang apabila akan digunakan untuk menganalisis perusahaan tidak publik.

Hasilnya, persamaan $Z$ Score berubah sebagai berikut (Newton, 2000: 56 ):

Dalam hal ini:

$$
Z=0,717 X_{1}+0,847 X_{2}+3,107 X_{3}+0,420 X_{4}+0,998 X_{5}
$$

$X_{1}=$ Modal Kerja/Total Aktiva

Modal kerja adalah selisih antara aktiva lancar dengan utang lancar. Total aktiva adalah total kekayaan perusahaan baik aktiva lancar maupun aktiva tetap. Modal kerja/Total aktiva merupakan rasio likuiditas yang paling valuable (Altman, 1993: 186).

$\mathrm{X}_{2}=$ Laba Ditahan/Total Aktiva.

Laba ditahan adalah laba yang diinvestasikan kembali. Laba ditahan/Total aktiva merupakan rasio leverage baru yang menunjukkan seberapa besar total aktiva perusahaan dibentuk oleh komponen laba ditahan (Altman, 1993: 186).

$X_{3}=E B I T / T o t a l$ Aktiva.

EBIT adalah penghasilan sebelum dikurangi bunga dan pajak. EBIT/Total aktiva merupakan rasio profitabilitas yang mengukur produktivitas asset perusahaan dalam menghasilkan laba (Altman, 1993: 186).

$\mathrm{X}_{4}=$ Harga Pasar Saham/Nilai Buku Total Hutang.

Harga pasar saham adalah nilai pasar saham, dimana merupakan gabungan nilai pasar seluruh saham baik saham preferen maupun saham biasa. Nilai buku total hutang adalah total hutang perusahaan baik hutang jangka pendek atau hutang jangka panjang. Rasio nilai pasar saham/nilai buku total utang termasuk rasio solvabilitas yang menunjukkan seberapa besar asset perusahaan dapat menurunkan nilai utang sebelum kewajiban melebihi asset dan perusahaan menjadi insolven (Bernstein dan Wild, 1998: 487). 
$X_{5}=$ Penjualan/Total Aktiva.

Rasio penjualan/total aktiva yang biasa disebut total assets turnover merupakan rasio aktivitas yaitu menunjukkan tingkat efisiensi penggunaan keseluruhan aktiva perusahaan di dalam menghasilkan volume penjualan tertentu (Altman, 1993: 186).

Penilaian kebangkrutan perusahaan diketahui dari Z Score dengan ambang batas dibawah 1,2. Perusahaan yang tidak mengalami kebangkrutan memiliki Z Score di atas 2,9. Daerah ambang batas antara 1,2 dan 2,9 merupakan "gray area". Menurut Altman, The area between 1,2 and 2,9 will defined as the "zone of ignorance" or "grey area" because of the susceptibility to error clasification (Altman, 1993: 186). Altman menemukan bahwa rasio keuangan (profitabilitas, likuiditas, dan solvabilitas) bermanfaat dalam memprediksi kebangkrutan dengan tingkat keakuratan 95\% untuk periode setahun sebelum perusahaan bangkrut, $72 \%$ untuk periode dua tahun sebelum perusahaan bangkrut, $48 \%$ untuk periode tiga tahun sebelum perusahaan bangkrut, dan $36 \%$ untuk periode lima tahun sebelum perusahaan bangkrut. Hasil penelitian Altman ini menunjukkan bahwa kekuatan prediksi rasio keuangan mengalami penurunan untuk periode waktu yang lebih lama (Altman, 1968 dalam Surifah, 2002).

\subsection{Faktor-Faktor Penyebab Perusahaan Mengganti Auditor}

Perusahaan publik sangat membutuhkan jasa auditor untuk menjamin kewajaran laporan keuangannya agar dapat dipercaya oleh masyarakat. Menyadari akan hal itu, KAP saling bersaing untuk memperoleh klien (perusahaan publik) dengan cara memberikan jasa audit terbaik. Klien dapat meminta jasa audit kepada KAP untuk audit yang pertama maupun untuk kondisi pergantian audit. Pergantian auditor oleh klien dapat disebabkan oleh banyak faktor, seperti (Boynton dan Kell, 1996: 191) ketidakpuasan perusahaan klien, keinginan untuk menurunkan fee audit, kebutuhan akan jasa-jasa profesional yang luas, merger antara perusahaan-perusahaan yang memiliki auditor yang berbeda dan merger di antara perusahaan-perusahaan KAP.

\subsection{Hubungan Potensi Kebangkrutan Perusahaan terhadap Pergantian Auditor dan Pengembangan Hipotesis \\ Menurut penelitian Schwartz dan Menon (1985), perusahaan yang berpotensi bangkrut} memiliki kecenderungan mengganti auditor karena di dalam lingkungan perusahaan yang sedang mengalami potensi kebangkrutan terdapat pengaruh yang besar pada ketegangan hubungan antara manajemen dan auditor yang menyebabkan putusnya hubungan kerja antara manajemen dan auditor. Hal inilah yang memicu terjadinya pergantian auditor. Potensi kebangkrutan yang dialami perusahaan menyebabkan manajemen perusahaan berusaha untuk mencegah kebangkrutan yang mengakibatkan likuidasi. Serangkaian keputusan manajemen dalam rangka mencegah kebangkrutan perusahaan dapat menimbulkan masalah dengan auditor yang mengakibatkan timbulnya dorongan kuat untuk mengganti auditor.

Hal-hal yang dapat mendorong manajemen mengganti auditor yaitu: permasalahan akibat perubahan metoda akuntansi, pendapat auditor yang tidak memuaskan, atau ketidakpuasan atas kinerja auditor (auditor gagal mendeteksi kelemahan-kelemahan signifikan pada pengendalian intern perusahaan dan banyak ketidaktelitian yang dilakukan dalam mengaudit catatan-catatan atau dokumen-dokumen perusahaan yang menyebabkan auditor tidak dapat menemukan kesalahan pencatatan yang bersifat material dalam laporan keuangan perusahaan).

Perusahaan yang berpotensi bangkrut mengalami keadaan dalam hal ini kewajiban finansialnya lebih besar daripada kekayaannya, jadi perusahaan yang berpotensi bangkrut mengalami perubahan negatif pada tingkat penghasilannya. Maka, pihak manajemen berusaha mengatasinya dengan mengubah metoda akuntasi untuk menekan penyajian informasi yang negatif atau menutupi kondisi keuangan perusahaan yang buruk. Dalam hal ini, manajemen perusahaan harus melakukan beberapa penyesuaian yang harus diungkapkan dan dinyatakan dalam laporan auditan. Jika keadaan ini terjadi dan hal tersebut tidak ditaati oleh manajemen 
Pengaruh Potensi Kebangrutan Perusahaan Publik (Th. Niken Setyorini dan A. Yanti Ardiati)

serta menyimpang dari prinsip akuntansi Indonesia, maka auditor tidak dapat memberikan pendapat wajar tanpa pengecualian (Unqualified Opinion). Pihak manajemen tidak puas dengan hasil keputusan audit, karena pendapat wajar dengan pengecualian (qualified opinion) dapat menyebabkan krisis kepercayaan masyarakat umum pada kelayakan laporan keuangan perusahaan. Permasalahan metoda akuntansi ini akan mendorong manajemen perusahaan untuk mengganti auditornya (Schwartz dan Menon, 1985).

Kecenderungan mengganti auditor di atas dilakukan perusahaan-perusahaan yang mengalami potensi kebangkrutan pada umumnya. Kecenderungan tersebut diketahui berdasarkan penelitian-penelitian yang telah dilakukan sebelumnya. Berdasarkan literatur akuntansi sebelumnya, hipotesis dalam penelitian ini adalah:

$H_{1}=$ Potensi kebangkrutan yang dialami perusahaan publik mempengaruhi pergantian auditor.

\section{METODA PENELITIAN}

\subsection{Pemilihan Sampel dan Metoda Pengumpulan Data}

Sumber data yang dikumpulkan berasal dari data sekunder. Data yang dikumpulkan meliputi elemenelemen dalam laporan keuangan yang akan digunakan untuk menghitung rasio-rasio keuangan dalam persamaan Z Score. Peneliti mengumpulkan data dari Indonesian Capital Market Directory yang diterbitkan Bursa Efek Jakarta dan Annual Report perusahaan tahun 1998, 1999, 2000, dan 2001 dari PT. Rifan Financindo Cabang Universitas Atma Jaya Yogyakarta.

Penentuan sampel perusahaan menggunakan purposive random sampling dengan kriteria: perusahaan manufaktur yang terdaftar di BEJ dan tergolong jenis perusahaan consumer goods, perusahaan yang sudah terdaftar di BEJ pada tahun 1998, dan perusahaan yang melakukan pergantian auditor.

Penelitian menggunakan perusahaan manufaktur sebagai sampel penelitian karena dalam analisis $Z$ Score Altman memiliki pernyataan kesimpulan bahwa diskriminan Altman dinyatakan sebagai alat prediksi untuk perusahaan pabrikan dan industri lain (Muji dan Anies, 1995 dalam Supardi dan Sri Mastuti, 2003). Penelitian ini menggunakan perusahaan manufaktur jenis consumer goods karena perusahaan consumer goods selalu mempunyai permintaan konsumen yang tinggi dan tidak terpengaruh oleh kondisi perekonomian seperti krisis ekonomi. Penelitian Surifah, 2002 menghasilkan kesimpulan sementara bahwa rasio keuangan tidak dapat digunakan untuk memprediksi kebangkrutan pada masa krisis karena dipengaruhi secara dominan oleh krisis ekonomi (Surifah, 2002). Maka dari itu, penelitian ini mengambil sampel perusahaan consumer goods yang tidak dipengaruhi secara dominan oleh krisis ekonomi sehingga prediksi kebangkrutan menggunakan rasio keuangan dapat diterapkan.

Periode penelitian ditetapkan 4 tahun dari tahun 1998 sampai dengan 2001 agar penelitian dapat mewakili kondisi setelah terjadi krisis ekonomi pada pertengahan tahun 1997 yang mengakibatkan semakin banyaknya perusahaan yang mengalami kebangkrutan pada tahun 1998. Kriteria terakhir yaitu sampel perusahaan diambil berdasarkan jenis perusahaan publik yang melakukan penggantian auditor supaya sampel penelitian dapat mewakili perusahaan yang ganti auditor maupun perusahaan yang tidak ganti auditor. Berdasarkan tiga kriteria di atas, jenis perusahaan yang diambil sebagai sampel yaitu: perusahaan food and beverage dan perusahaan pharmaceuticals. Oleh karena jenis perusahaan consumer goods yang lain tidak melakukan penggantian auditor, yaitu perusahaan Tembakau (Tobacco Manufacturers), perusahaan Kosmetik dan Kebutuhan Rumah Tangga (Cosmetics and Household), dan perusahaan Perabotan Rumah Tangga (Houseware) maka perusahaan ini tidak dijadikan sebagai sampel.

Dari kriteria di atas, sampel yang digunakan dalam penelitian ini adalah perusahaan food and beverage dan pharmaceuticals. Tabel 1 menunjukkan penentuan sample yang digunakan dalam penelitian ini. 
KINERJA, Volume 10, No.1, Th. 2006: Hal. 76-87

Tabel 1

Sampel Penelitian

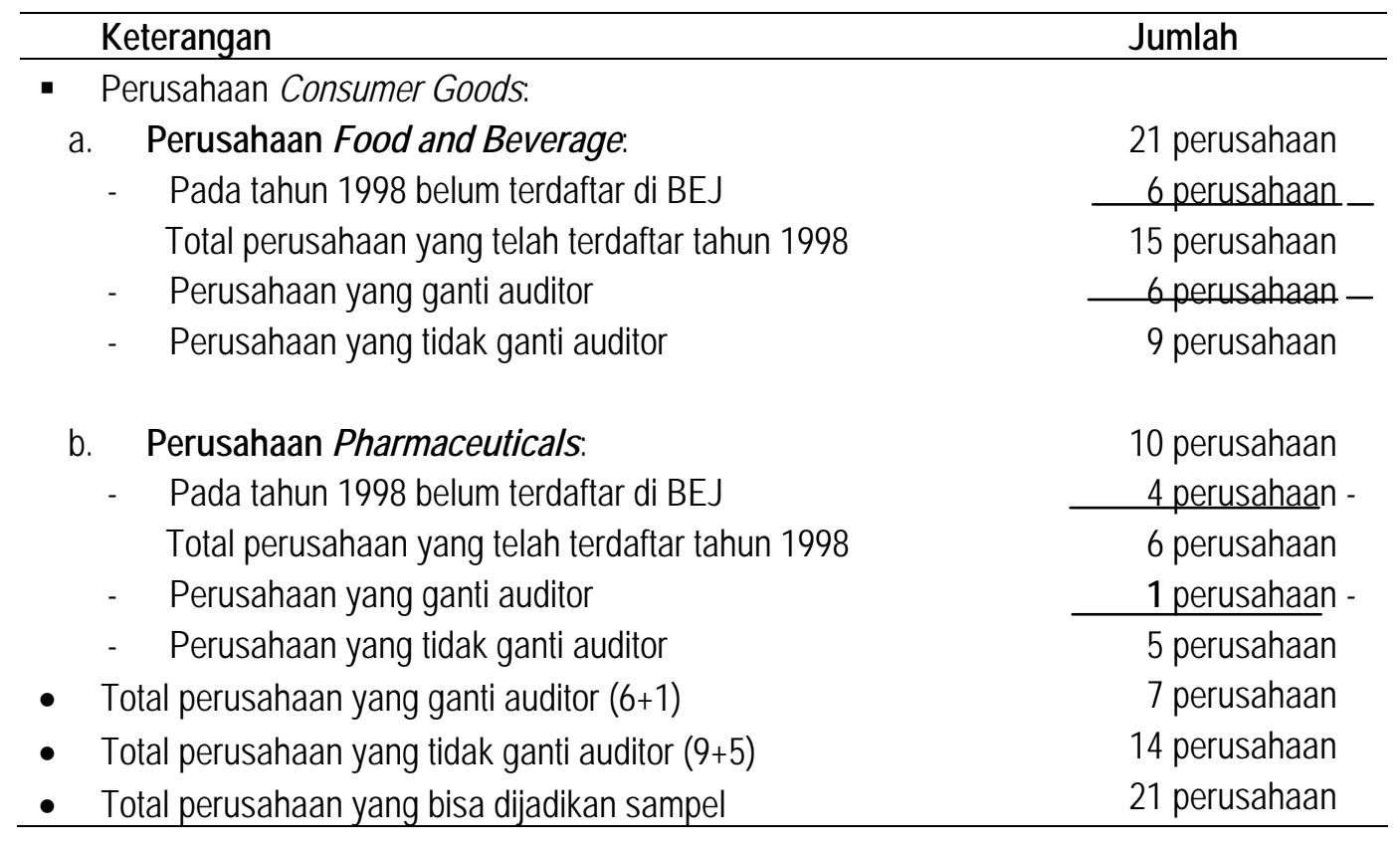

Total perusahaan yang bisa dijadikan sampel yaitu 21, terdiri dari 7 perusahaan yang ganti auditor dan 14 perusahaan yang tidak ganti auditor. Karena perusahaan yang ganti auditor ada 7, maka sebagai kontrolnya diambil 7 perusahaan dari 14 perusahaan yang tidak ganti auditor. Jadi total sampel penelitian ada 14 perusahaan.

\section{2. Definisi Operasional Variabel}

Variabel yang digunakan dalam penelitian adalah potensi kebangkrutan sebagai independent variable, diukur dengan menggunakan multivariate discriminan analysis Altman Z-Score dan pergantian auditor sebagai dependent variable.

\section{3. Alat Analisis Data}

Data pada penelitian ini merupakan data nonparametrik, karena sampel yang digunakan kecil yaitu $<30$. Selain itu data penelitian ini termasuk data multinomial, jadi untuk mengatasi penelitian semacam ini digunakan alat statistik Chi-Square Pearson dengan simbol $\chi^{2}$ (Dajan, 1986: 277). Kemudian untuk uji keeratan antara dua variabel, digunakan koefisien korelasi Phi $\left(r_{0}\right)$. Langkah-langkah menganalisis data menggunakan Chi-Square Pearson adalah:

a. Hasil perhitungan Z Score masing-masing perusahaan tahun 1998, 1999, 2000, dan 2001 dikategorikan bangkrut atau tidak bangkrut (lihat lampiran 1).

b. Melakukan uji pengaruh potensi kebangkrutan terhadap pergantian auditor dengan Chi-Square menggunakan SPSS 10.0 for windows (lihat lampiran 2).

c. Menarik kesimpulan dari hasil pengolahan data apakah $\mathrm{H}_{0}$ diterima atau ditolak.

\section{ANALISIS HASIL DAN PEMBAHASAN}

Tabel 2 menunjukkan hasil pengolahan data. 
Tabel 2

Pengaruh Potensi Kebangkrutan pada Pergantian Auditor

\begin{tabular}{ccc}
\hline Keterangan & Nilai & Probabilitas \\
\hline Koefisien korelasi Phi $\left(\mathrm{r}_{0}\right)$ & 0,31 & 0,237 \\
& 6 & \\
Chi-Square Pearson $\left(\chi^{2}\right)$ & 1,40 & 0,237 \\
& 0 & \\
\hline
\end{tabular}

Sumber: Data dioleh

Hasil olahan Chi-Square Pearson menunjukkan nilai $\chi^{2}$ Pearson sebesar 0.316 dengan probabilitas 0.237 yang berarti $\mathrm{H}_{1}$ yang menyatakan potensi kebangkrutan yang dialami perusahaan publik mempengaruhi pergantian auditor, tidak dapat didukung. Dengan demikian dapat disimpulkan bahwa peneliti tidak berani menolak $\mathrm{H}_{0}$.

\section{SIMPULAN}

Dari hasil analisis yang dilakukan dapat disimpulkan bahwa potensi kebangkrutan perusahaan publik tidak mempengaruhi pergantian auditor, karena diduga adanya beberapa factor yaitu: pertama, di Indonesia, perusahaan-perusahaan akan mempertimbangkan secara serius tentang masalah pergantian auditor karena auditor yang selama ini mereka gunakan telah mengetahui dan mengerti kondisi perusahaan. Jika perusahaan mengganti auditor, perusahaan khawatir jika auditor yang baru akan melakukan pemeriksaan terhadap sistem pembukuan dan menilai rendah standar mutu pembukuan perusahaan mereka. Hal ini dapat mengakibatkan keterlambatan penyajian laporan keuangan yang membuat perusahaan menanggung biaya denda keterlambatan. Kedua, adanya benturan kepentingan pada auditor dalam melaksanakan tugas audit dan memberikan jasa konsultan. Benturan kepentingan ini dapat mengganggu independensi auditor yang akan mempengaruhi opini audit. Perusahaan di Indonesia merasa hal tersebut dapat memberikan keuntungan, sehingga perusahaan enggan melakukan pergantian auditor.

Penelitian ini memiliki keterbatasan, yaitu: sampel penelitian kecil karena pengambilan sampel terbatas pada jenis perusahaan consumer goods dengan kriteria jenis perusahaan yang melakukan pergantian auditor.

\section{DAFTAR PUSTAKA}

Altman, E. I., (1968), "Financial Ratios, Discriminant Analysis and the Predictor of Corporate Bankruptcy", The Journal of Finance.

Altman, E. I., and M. Brenner, (1981), "Information Effects and Stock Market Response to signs of Firms Deterioration", Journal of Financial and Quantitative Analysis.

Altman, E. I., (1993), Corporate Financial Distress and Bankruptcy, 2nd Edition, John Willey and Son, New York.

Bernstein, Leopold A. and John J. Wild, (1998), Financial Statement Analysis Theory, Application and Interpretation, $6^{\text {th }}$ Edition, Mc.Graw Hill

Bowlin, O.D., Martin, J.D., and Scott, D.F., (1980), Guide To Financial Analysis, 2nd Edition, New York: McGraw-Hill Co., Inc. 
KINERJA, Volume 10, No.1, Th. 2006: Hal. 76-87

Boynton William, C., and Kell Walter, G., (1996), Modern Auditing, 6 6 $^{\text {th }}$ Edition, $\quad$ New York: John Willey and Sons, Inc.

Dajan, Anto, (1986), Pengantar Metode Statistik Jilid II, Perpustakaan Nasional: Katalog Dalam Terbitan (KDT).

Halim, Abdul, dan Setyorini, Mei, (2002), "Studi Potensi Kebangkrutan Perusahaan Publik di Bursa Efek Jakarta Tahun 1996-1998", Kompak.

"Indonesian Capital Market Directory", Jakarta: Bursa Efek Jakarta.

Scwartz, K.B., and K. Menon, April, (1985), "Auditor Switches by Failing Firm", The Accounting Review.

Supardi, dan Sri Mastuti, (2003), "Validitas Penggunaan Z-Score Altman Untuk Menilai Kebangkrutan pada Perusahaan Perbankan Go Publik di Bursa Efek Jakarta", Kompak. Januari-April.

Surifah, (2002), "Laporan Penelitian: Studi Tentang Rasio Keuangan Sebagai Alat Prediksi Kebangkrutan Perusahaan Publik Di Indonesia Pada Masa Krisis Ekonomi", Kajian Bisnis STIE Widya Wiwaha Yogyakarta, September- Desember. 
Lampiran 1

\begin{tabular}{|c|c|c|c|c|c|c|c|c|c|}
\hline \multirow[t]{2}{*}{ Nama Perusahaan } & \multicolumn{4}{|c|}{ Z Score } & \multirow{2}{*}{$\begin{array}{l}\text { Rata- } \\
\text { rata } \\
\end{array}$} & \multicolumn{3}{|c|}{ KAP } & \multirow[t]{2}{*}{ Keterangan } \\
\hline & 1998 & 1999 & 2000 & 2001 & & 1999 & 2000 & 2001 & \\
\hline $\begin{array}{l}1 \text { PT.Aqua Golden } \\
\text { Mississippi Tbk. }\end{array}$ & 2.9 & 2.6 & 2.3 & 2.1 & $2.5 \mathrm{~A}$ & $A$ & $A$ & $A$ & $\begin{array}{l}\text { Tidak bangkrut, } \\
\text { Tidak ganti auditor }\end{array}$ \\
\hline $\begin{array}{l}2 \text { PT.Cahaya Kalbar } \\
\text { Tbk. }\end{array}$ & 0.2 & 2.7 & 0.9 & 0.6 & $1.1 \mathrm{I}$ & H & H & H & $\begin{array}{l}\text { Bangkrut, Ganti } \\
\text { auditor }\end{array}$ \\
\hline $\begin{array}{l}3 \text { PT.Davomas Abadi } \\
\text { Tbk. }\end{array}$ & 1.1 & 0.9 & 0.1 & 0.8 & $0.7 \mathrm{~A}$ & A & J & $\mathrm{J}$ & $\begin{array}{l}\text { Bangkrut, Ganti } \\
\text { auditor }\end{array}$ \\
\hline $\begin{array}{l}4 \text { PT.Indofood Sukses } \\
\text { Makmur Tbk. }\end{array}$ & 1.8 & 2.4 & 2.0 & 1.9 & $2.0 \mathrm{~A}$ & A & A & A & $\begin{array}{l}\text { Tidak bangkrut, } \\
\text { Tidak ganti auditor }\end{array}$ \\
\hline $\begin{array}{l}5 \text { PT.Mayora Indah } \\
\text { Tbk. }\end{array}$ & 0.8 & 1.3 & 1.1 & 1.2 & $1.1 \mathrm{~B}$ & B & B & & $\begin{array}{l}\text { Bangkrut, Tidak } \\
\text { ganti auditor }\end{array}$ \\
\hline $\begin{array}{l}6 \text { PT.Prasidha Aneka } \\
\text { Niaga Tbk. }\end{array}$ & 1.8 & 1.0 & -2.9 & -1.4 & $-0.4 \mathrm{~A}$ & $A$ & & A & $\begin{array}{l}\text { Bangkrut, Tidak } \\
\text { ganti auditor }\end{array}$ \\
\hline $\begin{array}{l}7 \text { PT.Putra Sedjahtera } \\
\text { Pioneerindo Tbk. }\end{array}$ & -4.2 & 0.1 & -0.4 & 1.0 & -0.91 & $F$ & G & G & $\begin{array}{l}\text { Bangkrut, Ganti } \\
\text { auditor }\end{array}$ \\
\hline 8 PT.Sekar Laut Tbk. & -3.2 & -0.9 & -4.6 & -4.9 & $-3.4 \mathrm{~B}$ & B & C & C & $\begin{array}{l}\text { Bangkrut, Ganti } \\
\text { auditor }\end{array}$ \\
\hline $\begin{array}{l}9 \text { PT.Sierad Produce } \\
\text { Tbk. }\end{array}$ & -4.5 & -0.3 & 22 & & $-1.9 B$ & B & G & G & $\begin{array}{l}\text { Bangkrut, Ganti } \\
\text { auditor }\end{array}$ \\
\hline 10 PT.Suba Indah Tbk. & -0.1 & 1 & 1. & 0.2 & $0.6 \mathrm{~A}$ & A & B & B & $\begin{array}{l}\text { Bangkrut, Ganti } \\
\text { auditor }\end{array}$ \\
\hline $\begin{array}{l}11 \text { PT.Dankos } \\
\text { Laboratories Tbk. }\end{array}$ & & 2.7 & 2.1 & 2.4 & $1.7 \mathrm{~A}$ & A & A & A & $\begin{array}{l}\text { Tidak bangkrut, } \\
\text { Tidak ganti auditor }\end{array}$ \\
\hline $\begin{array}{r}12 \text { PT.Darya-Varia } \\
\text { Laboratoria Tbk. }\end{array}$ & & 2.2 & 0.9 & 1.1 & $0.8 \mathrm{E}$ & $E$ & $E$ & $\mathrm{E}$ & $\begin{array}{l}\text { Bangkrut, Tidak } \\
\text { ganti auditor }\end{array}$ \\
\hline 13 PT.Kalbe Farma Tbk. & -1.0 & 1.6 & 1.2 & 1.5 & $0.8 \mathrm{~A}$ & A & A & A & $\begin{array}{l}\text { Bangkrut, Tidak } \\
\text { ganti auditor }\end{array}$ \\
\hline $\begin{array}{l}14 \text { PT.Merck Indonesia } \\
\text { Tbk. }\end{array}$ & 2.5 & 3.3 & 4.3 & 4.1 & $3.6 \mathrm{D}$ & $F$ & $F$ & $F$ & $\begin{array}{l}\text { Tidak bangkrut, } \\
\text { Ganti auditor }\end{array}$ \\
\hline
\end{tabular}

\section{Keterangan:}

KAP di Indonesia yang bermitra dengan The big five CPA's:

A : Prasetyo, Utomo \& Co.

B : Hans Tuanakota \& Mustofa

C : E \& Y, Hanadi, Sarwoko\& Sandjaja

D : Siddharta Siddharta \& Harsono

E : Hadi Sutanto \& Rekan

KAP di Indonesia bukan mitra The big five CPA's:

$F$ : Hanadi Sudjendro \& Co

G : Amir Abadi Jusuf \& Aryanto

$\mathrm{H}$ : Rasin, Ichwan \& Co

I : Drs. Bambang Sulistiyanto \& Co

$\mathrm{J}$ : Paul Hadiwinata, Hidajat \& Co 


\section{Lampiran 2}

Crosstabs

\begin{tabular}{|c|c|c|c|c|c|c|}
\hline \multicolumn{7}{|c|}{ Case Processing Summary } \\
\hline & \multicolumn{6}{|c|}{ Cases } \\
\hline & \multicolumn{2}{|c|}{ Valid } & \multicolumn{2}{|c|}{ Missing } & \multicolumn{2}{|c|}{ Total } \\
\hline & $\mathrm{N}$ & Percent & $\mathrm{N}$ & Percent & $\mathrm{N}$ & Percent \\
\hline $\begin{array}{l}\text { Penggantian } \\
\text { Auditor * } \\
\text { Potensi } \\
\text { Kebangrutan }\end{array}$ & 14 & $100 \%$ & 0 & $0.0 \%$ & 14 & $100 \%$ \\
\hline
\end{tabular}

Penggantian Auditor * Potensi Kebangkrutan Crosstabulation

\begin{tabular}{|c|c|c|c|c|c|}
\hline & & & Potensi Ke & angkrutan & \\
\hline & & & Bangkrut & Bangkrut & Tota \\
\hline \multirow{6}{*}{$\begin{array}{l}\text { Penggantian } \\
\text { Auditor }\end{array}$} & Ganti & Count & & 1 & 7 \\
\hline & Auditor & Expected & & & \\
\hline & & Count & & 2.0 & 7.0 \\
\hline & Tidak & Count & 4 & 3 & 7 \\
\hline & Ganti & Expected & & & \\
\hline & Auditor & Count & 5.0 & 2.0 & 7.0 \\
\hline \multirow[t]{2}{*}{ Total } & & Count & 10 & 4 & 14 \\
\hline & & Count & 10.0 & 4.0 & 14.0 \\
\hline
\end{tabular}

\section{Chi-Square Tests}

\begin{tabular}{|c|c|c|c|c|c|}
\hline & Value & df & $\begin{array}{c}\text { Asymp. } \\
\text { Sig. } \\
\text { (2-sided) }\end{array}$ & $\begin{array}{c}\text { Exact } \\
\text { Sig. } \\
\text { (2-sided) }\end{array}$ & $\begin{array}{c}\text { Exact } \\
\text { Sig. } \\
\text { (1-sided) }\end{array}$ \\
\hline $\begin{array}{l}\text { Pearson } \\
\text { Chi-Square }\end{array}$ & $1.400 \mathrm{~b})$ & 1 & 0.237 & & \\
\hline Continuity a) & & & & & \\
\hline Correction & 0.350 & 1 & 0.554 & & \\
\hline Likelihood Ratio & 1.449 & 1 & 0.229 & & \\
\hline Fisher's Exact & & & & & \\
\hline Test & & & & 0.559 & 0.280 \\
\hline Linear-by-Linear & & & & & \\
\hline Association & 1.300 & 1 & 0.254 & & \\
\hline $\mathrm{N}$ of Valid Cases & 14 & & & & \\
\hline
\end{tabular}

a) Computed only for a $2 \times 2$ table

b). 2 cells (50.0\%) have expected count less than 5 . The minimum expected count is 2.00 . 
Pengaruh Potensi Kebangrutan Perusahaan Publik (Th. Niken Setyorini dan A. Yanti Ardiati)

\begin{tabular}{|c|c|c|c|c|c|}
\hline \multicolumn{6}{|c|}{ Symmetric Measures } \\
\hline & & \multicolumn{3}{|c|}{ Asymp } & \multirow{2}{*}{$\begin{array}{c}\text { Approx. } \\
\text { Sig. }\end{array}$} \\
\hline & & Value & Std. Error a) & Approx. T b) & \\
\hline \multirow[t]{4}{*}{ Nominal by Nominal } & Phi & 0.316 & & & 0.237 \\
\hline & Cramer's V & 0.316 & & & 0.237 \\
\hline & Contingency & & & & \\
\hline & Coefficient & 0.302 & & & 0.237 \\
\hline Interval by Interval & Pearson's R & 0.316 & 0.244 & 1.155 & $0.271 \mathrm{c})$ \\
\hline \multirow[t]{2}{*}{ Ordinal by Ordinal } & Spearman & & & & \\
\hline & Correlatio & 0.316 & 0.244 & 1.155 & $0.271 \mathrm{c})$ \\
\hline $\mathrm{N}$ of Valid Cases & & 14 & & & \\
\hline
\end{tabular}

a) Not assuming the null hypothesis.

b) Using the asymptotic standard error assuming the null hypothesis.

c) Based on normal 